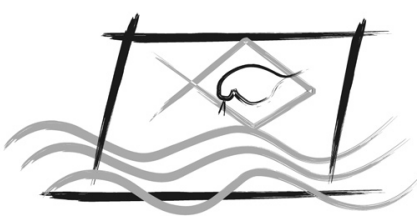

ECOTOX - BRASIL

\title{
Phytotoxicity of Soil Contaminated with Petroleum Derivatives and Biodiesel
}

\author{
J.M. Cruz ${ }^{1}$, P.R.M. Lopes ${ }^{1}$, R.N. Montagnolli ${ }^{1}$, I.S. TAmada ${ }^{1}$, N.M.M.G. Silva ${ }^{2} \&$ E.D. Bidoia ${ }^{1}$ \\ ${ }^{1}$ Universidade Estadual Paulista, UNESP, Departamento de Bioquímica e Microbiologia, IB, Av. 24 A, n. 1515, \\ Rio Claro, São Paulo, 13506-900, Brasil. \\ ${ }^{2}$ Universidade Estadual do Norte do Paraná, UENP, BR-369, Km 54, Bandeirantes, Paraná, 86360-000, Brasil.
}

(Received November 16, 2011; Accept August 26, 2012)

\begin{abstract}
The inhibition of root and hypocotyl elongation may reflect toxic substances in low concentrations, which are not sufficient to prevent germination, but may delay or inhibit root and hypocotyl growth. The objective of this study was to evaluate root and hypocotyl growth inhibition in Cucumis sativus, Brassica oleracea and Barbarea verna as a parameter for assessing soils toxicity when contaminated with diesel, lubricant oil and biodiesel. Thus, potential toxicity of contaminants was evaluated according to biodegradation time in soil by examining root and hypocotyl elongation inhibition. Results show that $C$. sativus root is the best indicator for diesel and lubricant oil reduced toxicity after biodegradation. It was also observed that biodiesel increases its toxicity after two months of biodegradation.
\end{abstract}

Keywords: bioassays, biodegradation, hydrocarbon, hypocotyl, root, seeds.

Fitotoxicidade de Solo Contaminado com Derivados do Petróleo e Biodiesel

\section{Resumo}

A inibição no alongamento da raiz e do hipocótilo pode refletir a presença de substâncias em concentrações baixas, que não são suficientes para impedir a germinação, mas podem atrasar ou inibir o alongamento da raiz e do hipocótilo. O objetivo deste trabalho foi avaliar a inibição do crescimento da raiz e hipocótilo de Cucumis sativus, Brassica oleracea e Barbarea verna como um parâmetro para avaliar a toxicidade do solo quando contaminado com diesel, óleo lubrificante e biodiesel. Assim, o potencial tóxico dos contaminantes foi avaliado de acordo com o tempo de biodegradação pela inibição no alongamento da raiz e do hipocótilo. Os resultados mostram que a raiz de C. sativus é o melhor indicador para demonstrar a redução da toxicidade de diesel e óleo lubrificante após biodegradação. Foi também observado que o biodiesel aumentou sua toxicidade após 2 meses de biodegradação.

Palavras-chave: bioensaios, biodegradação, sementes, hipocótilo, raiz, hidrocarbonetos. 


\section{INTRODUCTION}

The incomplete combustion of fossil fuels originates polycyclic aromatic hydrocarbons (PAHs). Some of these compounds are toxic, mutagenic and carcinogenic (Pashin \& Bakhitova, 1979). Nunes-Halldorson et al. (2004) compared the toxicity of two PAHs types, toluene e benzene, and found greater toxicity of toluene, which the $10 \mathrm{ppm}$ concentration is sufficient to kill half of Ceriodaphnia population exposed to the pollutant. Thus, less-polluting fuels are being sought. Biodiesel, which is composed of methyl or ethyl esters, offers advantages such as easy biodegradation and low toxicity (Zang et al., 2008; Mariano et al., 2008; Lapinskiene et al., 2006).

Environmental bioremediation is widely used based on the ability of microorganisms to biodegrade these compounds and decrease their toxicity (Vidali, 2001). Several microorganisms possess enzymatic ability to degrade hydrocarbon (Leahy \& Colwell, 1990).

The bacteria isolated from genus Ralstonia, Alcaligenes and Bacillus are specially capable of degrading hydrocarbons from petroleum-contaminated site (Plaza et al., 2008). However, few microorganisms can degrade complex structure hydrocarbon as PAHs with various aromatic rings (Atlas, 1995). Assessing biodegradation efficiency through chemical analysis does not necessarily shows the real impact each substance has on living organisms (Sisinno et al., 2007). Moreover, some compounds when degraded generate intermediate products that can be more toxic than original substance (Nunes-Halldorson et al., 2004).

Thus, the use of bioassays to assess toxicity of contaminated soil gained widespread attention in the last 20 years; these tests have proved to be useful for predicting the effect of a complex mixture such as petroleum (BaudGrasset et al., 1993; Banks et al., 2005). Plaza et al. (2005) used bacteria, protozoa, crustacea and seed development as bioindicators to evaluate remediation of contaminated soil by oil. These authors consider it necessary to combine bioassays with chemical data for a good soil quality assessment.

Plants used in ecotoxicological tests during the early seedling development, when numerous physiological processes occur, are sensitive to presence of toxic substances that interfere with both survival and growth. Therefore, root and hypocotyl elongation inhibition are sub-lethal indicators to assess the toxic potential of various contaminants (Sobrero $\&$ Ronco, 2004). Some studies found a decrease of toxicity in seedling development after the biodegradation of the pollutant (Baek et al., 2004; Molina-barahona et al., 2005; D'Souza et al., 2011).

The objective of this study was to evaluate the inhibition of root and hypocotyl growth of Cucumis sativus, Brassica oleracea and Barbarea verna as a parameter to measure the toxicity of soils contaminated with diesel, biodiesel and used lubricating oil according to biodegradation time.

\section{MATERIALS AND METHODS}

The sandy soil was obtained in a commercial establishment. Toxicity rates were evaluated by using three different substances: lubricant oil, collected at gas station in the city of Rio Claro-SP, biodiesel (Caramuru) and commercial diesel (B2 - 2\% biodiesel) purchased station Petrobras town of Rio Claro-SP. Untreated seeds of Barbarea verna (watercress), Brassica oleracea (kale) and Cucumis sativus (cucumber) - ISLA were used as bioindicator.

Table 1 presents the contaminated samples composition that was prepared according to an adapted Lopes \& Bidoia (2009) methodology. In preparing the test control, the volume of contaminant was replaced by distilled water.

The bags were perforated after mixing in order to establish contact with potential biodegrading microorganisms naturally present in soil. The bags were buried in Sao Paulo State University, Rio Claro (22,3968 S, $47,5454 \mathrm{~W})$. A sample of each contaminant was removed at an interval of 30 days and were defined as time zero, one time (30 days), time two (60 days), time three (90 days) and time four (120 days). Except the time zero (T0) that was tested immediately after contamination.

The toxicity test was conducted according to Morales (2004). Seeds were sown in plastic cups containing $50 \mathrm{~mL}$ of $50 \mathrm{~g}$ of contaminated sand. The tests were performed in triplicates containing 10 seeds each. To the positive control $2.5 \mathrm{~mL}$ of $0.05 \mathrm{M}$ zinc sulfate were added to evaluate seed sensitivity. The seedlings were removed and measurement for calculate the toxicity percentage (equation 1) according to Sobrero \& Ronco (2004).

Values of root and hypocotyl elongation were subjected to analysis of variance (ANOVA) using the Kruskal-Wallis test. Significant differences were accepted at $p<0,0001$.

Table 1 - Contaminated samples composition

\begin{tabular}{lcccc}
\hline Assays & $\begin{array}{c}\text { Contaminant } \\
(\mathrm{mL})\end{array}$ & $\begin{array}{c}\text { Sand } \\
(\mathrm{g})\end{array}$ & $\begin{array}{c}\text { Tween } 80^{\circledR} \\
(\mathrm{mL})\end{array}$ & $\begin{array}{c}\text { Distilled } \\
\text { water } \\
(\mathrm{mL})\end{array}$ \\
\hline Lubricant oil & 52.5 & 700 & 1.05 & 43.75 \\
Diesel & 52.5 & 700 & 1.05 & 43.75 \\
Biodiesel & 52.5 & 700 & 1.05 & 43.75 \\
Positive control & - & 700 & 1.05 & 96.25 \\
Negative control & - & 700 & 1.05 & 96.25 \\
\hline
\end{tabular}

$\%$ inhibition $=\frac{\text { mean negative control }- \text { mean sample treatment }}{x 100}$ 


\section{RESULTS AND DISCUSSION}

The inhibition percentage in Cucumis sativus development is presented in Figures 1 and 2.

Negative numbers in the graph were used in a representative way to demonstrate that cucumber had an unexpected response. Some assays presented a higher growth when compared to control test. However, the test organism should present the highest growth on control tests.

C. sativus root elongation in soil contaminated with diesel fuel significantly reduced the growth at the start of the experiment, but in $\mathrm{T} 3$ and $\mathrm{T} 4$ the growth reduction was not significant in relation to negative control (Table 2). Root development inhibition caused by diesel in T3 was only $10.04 \%$ compared to control (Fig. 1). However, the hypocotyl

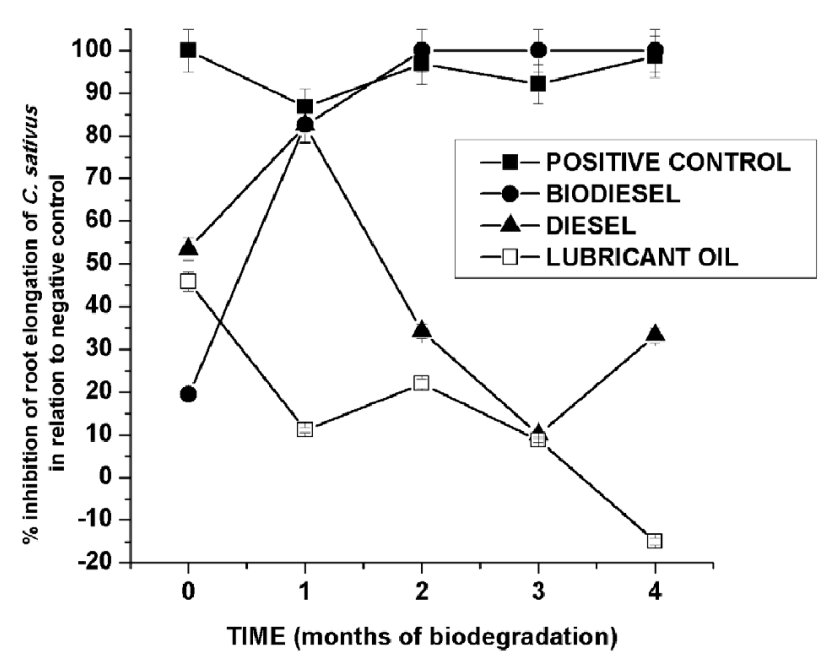

Figure 1. Inhibition percentage of root elongation of C. sativus in soil contaminated during biodegradation process.

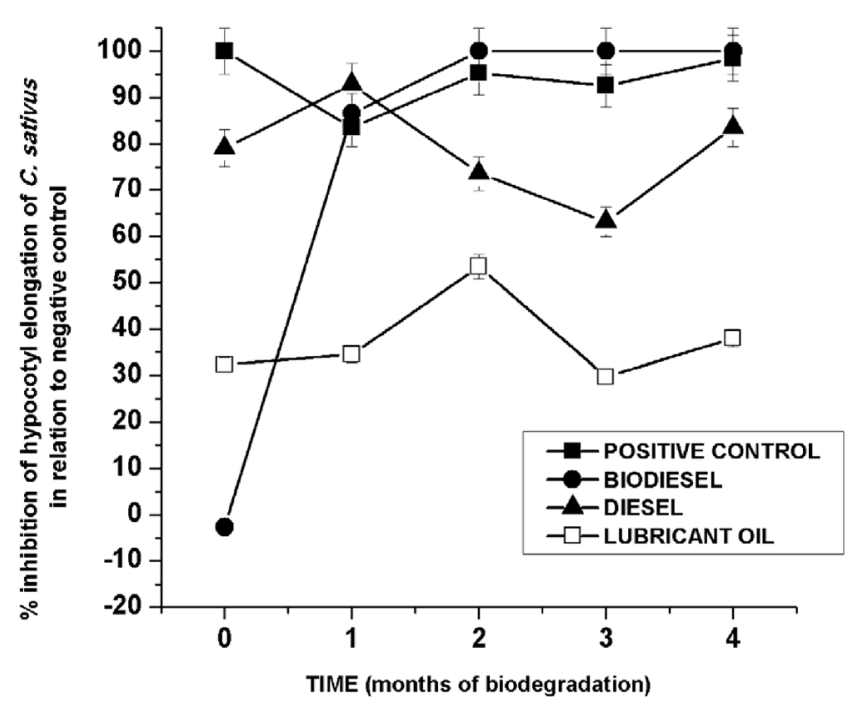

Figure 2. Inhibition percentage of hypocotyl elongation of $C$. sativus in soil contaminated during biodegradation process.
Table 2 - Mean of Cucumis sativus root elongation

\begin{tabular}{|c|c|c|c|c|c|}
\hline $\begin{array}{c}\text { root } C . \\
\text { sativus }\end{array}$ & Time 0 & Time 1 & Time 2 & Time 3 & Time 4 \\
\hline $\begin{array}{l}\text { Negative } \\
\text { Control }\end{array}$ & $4.54 \pm 2.54^{\mathrm{a}}$ & $6 \pm 2.19^{a}$ & $4.62 \pm 1.62^{\mathrm{a}}$ & $4.68 \pm 1.32^{\mathrm{a}}$ & $4.9 \pm 2.5^{\mathrm{ac}}$ \\
\hline Biodiesel & $3.84 \pm 1.84^{\mathrm{a}}$ & $1.04 \pm 1.28^{\mathrm{b}}$ & $0 \pm 0^{\mathrm{b}}$ & $0 \pm 0^{\mathrm{b}}$ & $0 \pm 0^{\mathrm{b}}$ \\
\hline Diesel & $0.26 \pm 0.68^{b}$ & $1.05 \pm 1.09^{\mathrm{b}}$ & $3.04 \pm 1.24^{\mathrm{c}}$ & $4.21 \pm 1.43^{\mathrm{a}}$ & $3.27 \pm 1.7^{\mathrm{a}}$ \\
\hline $\begin{array}{c}\text { Lubricant } \\
\text { oil }\end{array}$ & $0.75 \pm 1.22^{\mathrm{b}}$ & $5.34 \pm 2.36^{\mathrm{a}}$ & $3.60 \pm 1.37^{\mathrm{ac}}$ & $4.27 \pm 1.57^{\mathrm{a}}$ & $5.64 \pm 2.97^{\mathrm{c}}$ \\
\hline
\end{tabular}

Table 3 - Mean of Cucumis sativus hypocotyl elongation

\begin{tabular}{|c|c|c|c|c|c|}
\hline $\begin{array}{l}\text { hypocotyl } C \text {. } \\
\text { sativus }\end{array}$ & Time 0 & Time 1 & Time 2 & Time 3 & Time 4 \\
\hline $\begin{array}{l}\text { Negative } \\
\text { Control }\end{array}$ & $4.43 \pm 2.35^{\mathrm{a}}$ & $5.98 \pm 1.61^{\mathrm{a}}$ & $3.52 \pm 0.98^{\mathrm{a}}$ & $1.79 \pm 0.64^{\mathrm{a}}$ & $2.16 \pm 1.08^{\mathrm{a}}$ \\
\hline Biodiesel & $3.82 \pm 1.72^{\mathrm{b}}$ & $0.8 \pm 1.148^{\mathrm{b}}$ & $0 \pm 0^{\mathrm{b}}$ & $0 \pm 0^{\mathrm{b}}$ & $0 \pm 0^{\mathrm{b}}$ \\
\hline Diesel & $0.07 \pm 0.19^{\mathrm{b}}$ & $0.43 \pm 0.43^{\mathrm{b}}$ & $0.93 \pm 0.85^{\mathrm{c}}$ & $0.66 \pm 0.59^{c}$ & $0.35 \pm 0.24^{\circ}$ \\
\hline Lubricant oil & $0.62 \pm 1.07^{\mathrm{b}}$ & $5.34 \pm 2.36^{\mathrm{a}}$ & $1.63 \pm 0.8^{\mathrm{c}}$ & $1.26 \pm 0.54^{\mathrm{a}}$ & $1.34 \pm 0.81^{\circ}$ \\
\hline
\end{tabular}

elongation showed inhibition during all experiment period with no toxicity reduction (Fig 2). The low hypocotyl growth in soil contaminated with diesel coincides with findings by Ogbo (2009).

Used lubricant oil has no toxic potential in C. sativus root development. In T4, toxicity is represented by $-15.01 \%$, this means that compared to control test there was no inhibition. The root growth on the contaminant was greater than on control test (Fig. 1). According to Vwioko \& Fashemi (2005), low concentrations of used lubricant oil stimulated Ricinus communis growth. Table 2 shows the positive effect of the biodegradation process from the contaminated soil with used lubricant oil and diesel, which the growth reduction was not significant in relation to negative control. Soil samples contaminated with biodiesel, affected the root and hypocotyl development of $C$. sativus, reaching $100 \%$ inhibition at T2 (Fig. 1 and 2).

Inhibition percentage in the root and hypocotyl development of $B$. oleracea is shown in Figures 3 and 4.

The presence of diesel oil reduced root and hypocotyl growth of $B$. oleracea, especially at the beginning of contamination (Fig. 3 and 4). However, it may be noted that $\mathrm{T} 3$ there was a toxicity reduction in soil contaminated with diesel oil. According to Baek (2004) after the bioremediation processes there is a better plant growth.

The kale seedlings development was very sensitive to the used lubricant oil. The root elongation showed high levels of inhibition; despite a lower toxicity demonstrated by the hypocotyl after 3 months of soil incubation (Fig. 4). Thus was observed 


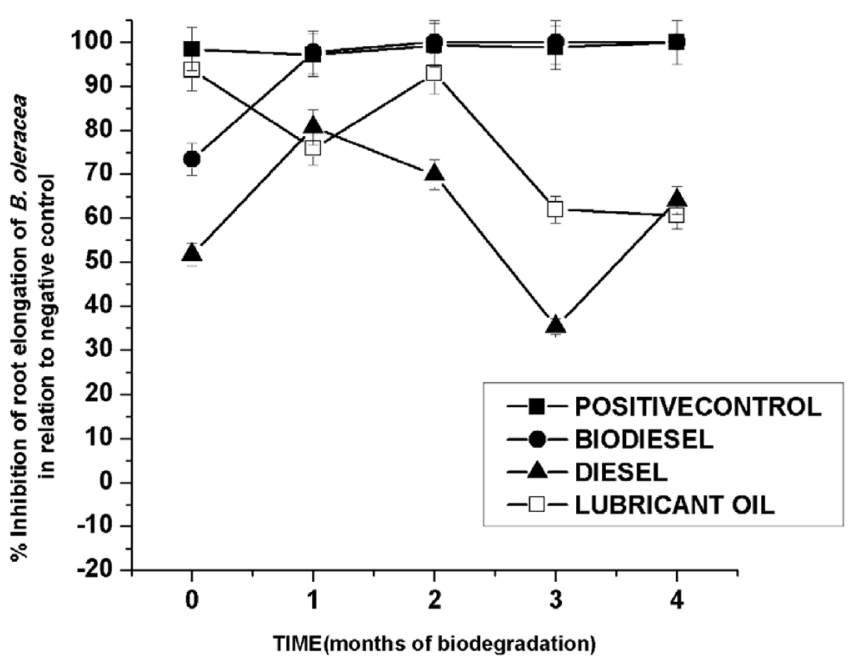

Figure 3. Inhibition percentage of root elongation of $B$. oleracea in soil contaminated during biodegradation process.

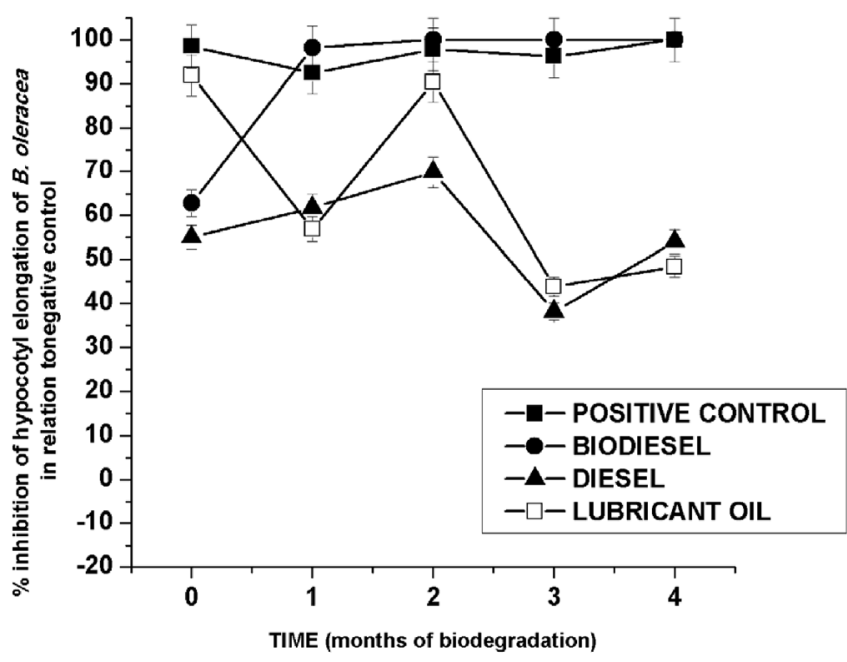

Figure 4. Inhibition percentage of hypocotyl elongation of $B$. oleracea in soil contaminated during biodegradation process.

that the hypocotyl growth mean not was significant in relation to negative control, in other words, the process biodegradation of diesel allowed a better hypocotyl elongation (Table 5).

The inhibitory effect of used lubricant oil for the seedlings development of kale may be related to the large amounts of PAHs present in its composition (Henry, 1998).

The kale showed great sensitivity in freshly contaminated soil with biodiesel, reaching $100 \%$ toxicity in T2.

The inhibition percentages in the contaminated soil are presented in Figures 5 and 6.

The root and hypocotyl development of $B$. verna had a high sensitivity for all contaminants, during all periods. Soil contaminated with used lubricant oil showed $100 \%$ toxicity for both root and hypocotyl of cress (Fig. 5 e 6). Inhibition caused by diesel oil was above $85 \%$ for both parameters and results for biodiesel reached $100 \%$ toxicity after 60 days as occurred for cucumber and kale.
Table 4 - Mean of Brassica oleracea root elongation

\begin{tabular}{|c|c|c|c|c|c|}
\hline $\begin{array}{l}\text { root } B . \\
\text { oleracea }\end{array}$ & Time 0 & Time 1 & Time 2 & Time 3 & Time 4 \\
\hline $\begin{array}{l}\text { Negative } \\
\text { Control }\end{array}$ & $2.58 \pm 2.15^{\mathrm{a}}$ & $3.2 \pm 2.23^{\mathrm{a}}$ & $\begin{array}{c}2.37 \\
\pm 1.73745^{\mathrm{a}}\end{array}$ & $1.37 \pm 1.11^{\mathrm{a}}$ & $2.23 \pm 1.59^{a}$ \\
\hline Biodiesel & $0.68 \pm 0.71^{b}$ & $0.07 \pm 0.28^{b}$ & $0 \pm 0^{\mathrm{b}}$ & $0 \pm 0^{\mathrm{b}}$ & $0 \pm 0^{\mathrm{b}}$ \\
\hline Diesel & $0.79 \pm 0.95^{b}$ & $0.62 \pm 0.75^{b}$ & $0.71 \pm 0.99^{c}$ & $0.89 \pm 0.75^{\mathrm{a}}$ & $0.8 \pm 0.85^{\mathrm{c}}$ \\
\hline Lubricant & $0.79 \pm 0.95^{b}$ & $0.77 \pm 1.02^{\mathrm{b}}$ & $0.16 \pm 0.37 b^{c}$ & $0.52 \pm 0.61^{\mathrm{a}}$ & $0.88 \pm 1.05^{\mathrm{c}}$ \\
\hline
\end{tabular}

Table 5 - Mean of Brassica oleracea hypocotyl elongation

\begin{tabular}{|c|c|c|c|c|c|}
\hline $\begin{array}{l}\text { hypocotyl } \\
\text { B. } \\
\text { oleracea }\end{array}$ & Time 0 & Time 1 & Time 2 & Time 3 & Time 4 \\
\hline $\begin{array}{l}\text { Negative } \\
\text { Control }\end{array}$ & $2.22 \pm 1.81^{\mathrm{a}}$ & $1.84 \pm 1.47^{\mathrm{a}}$ & $1.56 \pm 1.38^{\mathrm{a}}$ & $0.7 \pm 0.56^{a}$ & $0.82 \pm 0.64^{\mathrm{a}}$ \\
\hline Biodiesel & $0.82 \pm 0.97058^{\mathrm{a}}$ & $0.03 \pm 0.10^{\mathrm{b}}$ & $0 \pm 0^{\mathrm{b}}$ & $0 \pm 0^{\mathrm{b}}$ & $0 \pm 0^{\mathrm{b}}$ \\
\hline Diesel & $0.63 \pm 0.77925^{\mathrm{b}}$ & $0.70 \pm 0.88^{\mathrm{b}}$ & $0.47 \pm 0.64^{\mathrm{c}}$ & $0.43 \pm 0.4^{\mathrm{a}}$ & $0.38 \pm 0.39^{\mathrm{a}}$ \\
\hline $\begin{array}{l}\text { Lubricant } \\
\text { oil }\end{array}$ & $0.18 \pm 0.42^{\mathrm{b}}$ & $0.7 \pm 0.88^{b}$ & $0.15 \pm 0.39^{\mathrm{bc}}$ & $0.39 \pm 0.43^{\mathrm{a}}$ & $0.42 \pm 0.51^{\mathrm{a}}$ \\
\hline
\end{tabular}

The inhibitory effect for $B$. verna is not only due to contaminants, since no pollutant was added to negative control test. However, the species had not achieved $65 \%$ germination, which is a minimum rate to ensure the toxic effect of the contaminant in the development of root and hypocotyl (U.S. EPA, 1996), the growth mean was low even in the negative control (Table 6 and Table 7).

C. sativus root growth was the best indicator to evaluate the toxicity reduction of diesel oil and used lubricant oil after 90 days, supporting references that consider $C$. sativus root

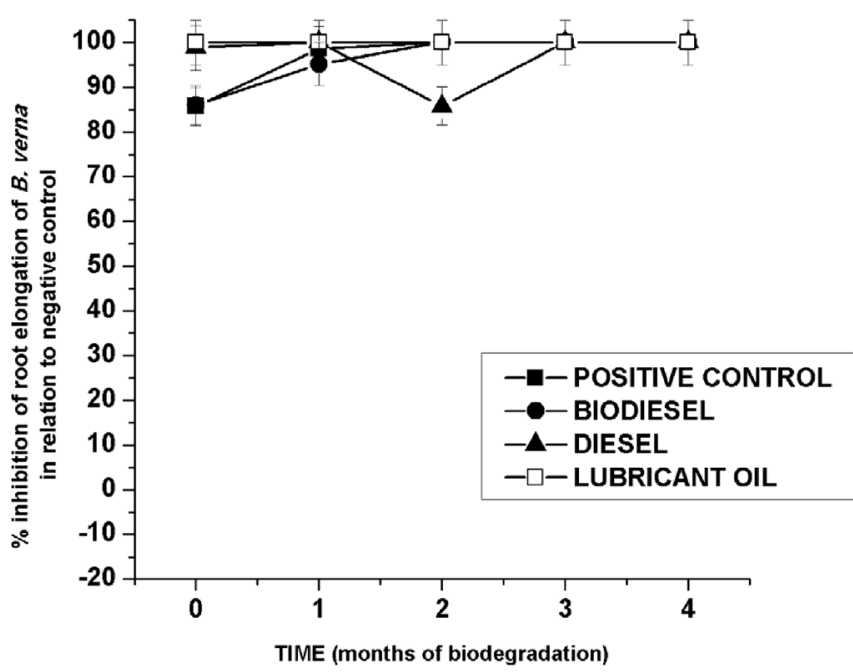

Figure 5. Inhibition percentage of root elongation of $B$. verna in soil contaminated during biodegradation process. 


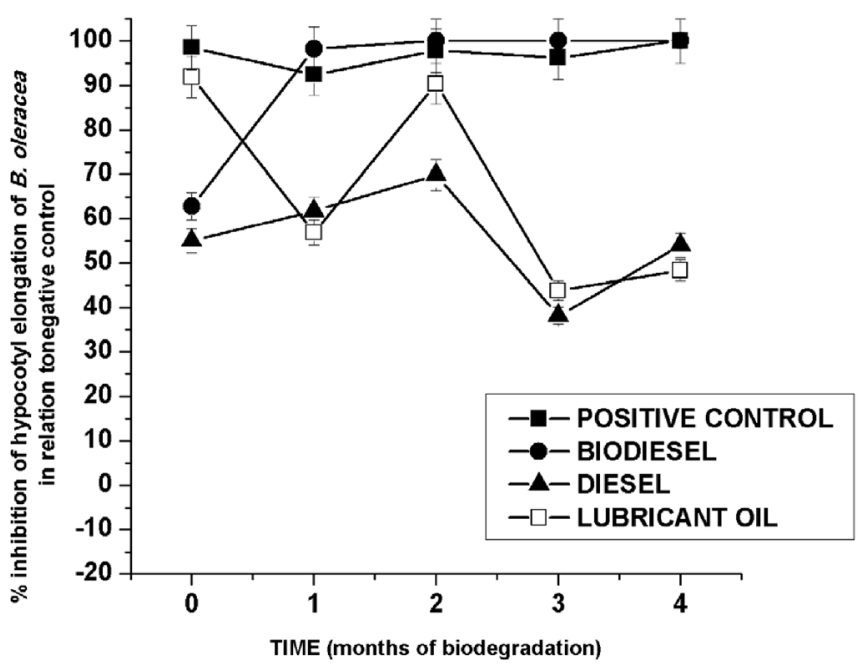

Figure 6. Inhibition percentage of hypocotyl elongation of $B$. verna in soil contaminated during biodegradation process.

Table 6 - Mean of Barbarea verna root elongation

\begin{tabular}{lccccc}
\hline $\begin{array}{l}\text { root } \boldsymbol{B} . \\
\text { verna }\end{array}$ & Time 0 & Time 1 & Time 2 & Time 3 & Time 4 \\
\hline $\begin{array}{l}\text { Negative } \\
\text { Control }\end{array}$ & $1.09 \pm 0.91^{\mathrm{a}}$ & $1.18 \pm 0.88^{\mathrm{a}}$ & $1.33 \pm 0.92^{\mathrm{a}}$ & $0.71 \pm 0.55^{\mathrm{a}}$ & $0.35 \pm 0.65^{\mathrm{a}}$ \\
Biodiesel & $0.15 \pm 0.25^{\mathrm{b}}$ & $0.05 \pm 0.13^{\mathrm{b}}$ & $0 \pm 0^{\mathrm{b}}$ & $0 \pm 0^{\mathrm{b}}$ & $0 \pm 0^{\mathrm{a}}$ \\
Diesel & $0.01 \pm 0.07^{\mathrm{b}}$ & $0 \pm 0^{\mathrm{b}}$ & $0.19 \pm 0.38^{\mathrm{b}}$ & $0 \pm 0^{\mathrm{b}}$ & $0 \pm 0^{\mathrm{a}}$ \\
Lubricant oil & $0 \pm 0^{\mathrm{b}}$ & $0 \pm 0^{\mathrm{b}}$ & $0 \pm 0^{\mathrm{b}}$ & $0 \pm 0^{\mathrm{b}}$ & $0 \pm 0^{\mathrm{a}}$ \\
\hline
\end{tabular}

Values correspond to the mean \pm standard deviation. Significant differences among treatments within a Time are followed by different letters $(\mathrm{p}<0.0001)$ according to Kruskal-Wallis test.

Table 7 - Mean of Barbarea verna hypocotyl elongation

\begin{tabular}{lccccc}
\hline $\begin{array}{l}\text { hypocotyl } \boldsymbol{B} . \\
\text { verna }\end{array}$ & Time 0 & Time 1 & Time 2 & Time 3 & Time 4 \\
\hline $\begin{array}{l}\text { Negative } \\
\text { Control }\end{array}$ & $0.85 \pm 0.72^{\mathrm{a}}$ & $0.74 \pm 0.54^{\mathrm{a}}$ & $1 \pm 0.8^{\mathrm{a}}$ & $0.37 \pm 0.26^{\mathrm{a}}$ & $0.22 \pm 0.41^{\mathrm{a}}$ \\
Biodiesel & $0.22 \pm 0.38^{\mathrm{b}}$ & $0.05 \pm 0.12^{\mathrm{b}}$ & $0 \pm 0^{\mathrm{b}}$ & $0 \pm 0^{\mathrm{b}}$ & $0 \pm 0^{\mathrm{a}}$ \\
Diesel & $0.01 \pm 0.07^{\mathrm{b}}$ & $0 \pm 0^{\mathrm{b}}$ & $0.06 \pm 0.11^{\mathrm{b}}$ & $0 \pm 0^{\mathrm{b}}$ & $0 \pm 0^{\mathrm{a}}$ \\
Lubricant oil & $0 \pm 0^{\mathrm{b}}$ & $0 \pm 0^{\mathrm{b}}$ & $0 \pm 0^{\mathrm{b}}$ & $0 \pm 0^{\mathrm{b}}$ & $0 \pm 0^{\mathrm{a}}$ \\
\hline
\end{tabular}

Values correspond to the mean \pm standard deviation. Significant differences among treatments within a Time are followed by different letters $(\mathrm{p}<0.0001)$ according to Kruskal-Wallis test.

growth a sensitive toxicity indicator (Wang et al., 2001). The root growth inhibition of B. oleracea and B. verna in the presence diesel oil, can be caused by impermeability effect because the oil hydrophobic properties, influencing the absorption of water and nutrients (Adam \& Duncan, 2002).

The PAHs in diesel oil may induce a disturbance in plants development (Meudec, 2007). Nevertheless, some PAHs are more soluble than aliphatic hydrocarbons and its toxicity decrease after bioremediation process (Molina-barahona et al., 2005). Thus, the C. sativus and B. oleracea response corroborate with this assertion, because were less inhibited by diesel oil after biodegradation.
The inhibitory effect on the seedlings development in soil contaminated with used lubricant oil may be related to large amounts of PAHs present in its composition (Henry, 1998), besides that there are heavy metals coming from the engine parts as the oil is being used. Thereby the oil concentration increases in soil and $\mathrm{pH}$ value decreases, providing an acidic environment that increases the availability of these metals present on oil to the plants (Odjegba \& Atebe, 2007; Okonokhua et al., 2009). However, certain metals are required in small amounts to ensure improved vegetation growth, because high concentrations of these metals alter functions of plasmatic membrane and reduce cell growth (Wong \& Bradshaw, 1982; Janicka-Russak et al., 2008). Accordingly, the excess metals may have adversely affected the species development used in this study.

Used lubricant oil changes the soil properties reducing nitrogen and phosphorus concentration in the soil. These nutrients are essential for the microorganisms to degrade the contaminant and reduce toxicity to plants (Okonokhua et al., 2009). The C. sativus did not present the same inhibition viewed for kale and cress in soil contaminated with used lubricant oil. In this case, after 120 days of incubation, the used lubricant oil seems to stimulate root growth compared to the control test (Fig. 1). This is because after biodegradation, there is an increase in organic matter that can improve soil fertility (Vwioko \& Fashemi, 2005).

For contamination with biodiesel, the test organisms showed results in common, all achieved toxicity $100 \%$ after 60 days, so it suggests that there was biodegradation after 60 days of soil incubation. The acidity of the biodiesel increases, when it is degraded, because the fatty acid methyl ester molecules are broken down during degradation and the fatty acid chains, thus the acidity generated could affect the process of germination and consequently, the root and hypocotyl development (Lapinskiene et al., 2006; Leung et al., 2006).

The results with $B$. verna are not conclusive due to low germination in control test. Thus, the high percentage of toxicity cannot be only as an action of the contaminant (Morales, 2004).

Finally, the root elongation in C. sativus was the best parameter to evaluate toxicity reduction of diesel oil and used lubricant oil after four months. It was also noticed that biodiesel increases its toxicity after 2 months of biodegradation, thus there was no root and hypocotyl development.

\section{ACKNOWLEDGMENTS}

The authors acknowledge the financial support of the following agencies: Petrobras-PRH-05, CNPq, FAPESP, CAPES.

\section{REFERENCES}

ADAM, G. \& DUNCAN, H., 2002, Influence of diesel fuel on seed germination. Environ. Pollut., 120: 363-370. http://dx.doi. org/10.1016/S0269-7491(02)00119-7. 
ATLAS, R.M., 1995, Petroleum biodegradation and oil spill bioremediation. Mar. Pollut. Bull., 31: 178-182. http://dx.doi. org/10.1016/0025-326X(95)00113-2.

BAEK, K., KIM, H., OH, H., YOON, B., KIM, J., LEE, I., 2004, Effects of crude oil, oil components and bioremediation on plant growth. J. Environ. Sci. Heal. A, A39: 465-2472. http://dx.doi. org/10.1081/LESA-200026309.

BANKS, M.K. \& SCHULTZ, K.E., 2005, Comparison of plants for germination toxicity tests in petroleum-contaminated soils. Water Air Soil Poll, 167: 211-219. http://dx.doi.org/10.1007/ s11270-005-8553-4.

BAUD-GRASSET, F, BAUD-GRASSET, S, SAFFERMAN, S.I., 1993, Evaluation of the bioremediation of a contaminated soil with phytotoxicity tests. Chemosphere, 26: 1365-1374. http:// dx.doi.org/10.1016/0045-6535(93)90187-A.

D'SOUZA, R., VARUN, M., PAUL, M.S., 2011, Assessment of wheat bioassays as a monitoring system for phytoremediation of diesel. Biotechnol. Bioinf. Bioeng., 1: 125-130.

HENRY, J.A., 1998, Composition and toxicity of petroleum products and their additives. Hum. Exp. Toxicol., 17: 111-123. http:// dx.doi.org/10.1191/096032798678908350.

JANICKA-RUSSAK， M，KABALA，K., BURZYNSKI， M, KLOBUS, G., 2008, Response of plasma membrane $\mathrm{H}^{+}$ATPase to heavy metal stress in Cucumis sativus roots. J. Exp. Bot., 59: 3721-3728. http://dx.doi.org/10.1093/jxb/ern219.

LAPINSKIENE, A., MARTINKUS, P., REBŽDAITE, V., 2006, Eco-toxicological Studies of Diesel and Biodiesel Fuels in aerated soil. Environ. Pollut., 142: 432-437. http://dx.doi.org/10.1016/j. envpol.2005.10.023.

LEAHY, J.G. \& COLWELL, R.R. (1990) Microbial degradation of hydrocarbons in the environment. Microbiol. Rev., 54: 305-315.

LEUNG, D. Y. C., KOO, B. C. P., GUO, Y., 2006, Degradation of biodiesel under different storage conditions. Bioresource technol., v. 97: 250-256. http://dx.doi.org/10.1016/j. biortech.2005.02.006.

LOPES, P.R.M. \& BIDOIA, E.D., 2009, Evaluation of the biodegradation of different types of lubricant oils in liquid medium. Braz. Arch. Biol. Techn., 52: 1285-1290. http://dx.doi. org/10.1590/S1516-89132009000500028.

MARIANO, A.P., TOMASELLA, R.C., OLIVEIRA, L.M., CONTIERO, J., ANGELIS, D.F., 2008, Biodegradability of diesel and biodiesel blends. Afr. J. Biotechnol., 7: 1323-1328.

MEUDEC, A., POUPART, N., DUSSAUZE, J., DESLANDES, E., 2007, Relationship between heavy fuel oil phytotoxicity and polycyclic aromatic hydrocarbon contamination in Salicornia fragilis. Sci. Total. Environ., 381: 146-156. http://dx.doi. org/10.1016/j.scitotenv.2007.04.005.

MOLINA-BARAHONA, L., VEJA-LOYO, L., GUERRERO, M., RAMÍREZ, S., ROMERO, I., VEJA-JARQUÍN, C., ALBORES, A., 2005, Ecotoxicological evaluation of diesel-contaminated soil before and after a bioremediation process. Environ. Toxicol., 20: 100-1009. http://dx.doi.org/10.1002/tox.20083.

MORALES, G.C., 2004, Ensayos Toxicológicos y Métodos de Evaluación de Calidad de Agua: estandarización, intercalibración, resultados y aplicaciones. IMTA, México, 189p.

NUNES-HALLDORSON, V.S., STEINER, R.L., SMITH, G.B., 2004, Residual toxicity after biodegradation: interactions among benzene, toluene, and chloroform. Ecotox. Environ. Safe, 57:
162-167. http://dx.doi.org/10.1016/S0147-6513(03)00032-0.

ODJEGBA, V.J. \& ATEBE, J.O., 2007, The effect of used engine oil on carbohydrate, mineral content and nitrate reductase activity of leafy vegetable (Amaranthus hybridus L.). J. Appl. Sci. Environ. Manag., 11: 191-196. http://dx.doi.org/10.4314/jasem. v11i2.55039.

OGBO, E.M., 2009, Effects of diesel fuel contamination on seed germination of four crop plants - Arachis hypogaea, Vigna unguiculata, Sorghum bicolor and Zea mays. Afr. J. Biotechnol., 8: 250-253.

OKONOKHUA, B.O., IKHAJIAGBE, B., ANOLIEFO, G.O., EMEDE, T.O., 2007, The Effects of Spent Engine Oil on Soil Properties and Growth of Maize (Zea mays L.). J. Appl. Sci. Environ. Manag., 11: 147-152. http://dx.doi.org/10.4314/jasem. v11i3.55162.

PASHIN, Y.V. \& BAKHITOVA, L.M., 1979, Mutagenic and Carcinogenic Properties of Polycyclic Aromatic Hydrocarbons. Environ. Health Persp., 30: 185-189. http://dx.doi. org/10.2307/3429123.

PLAZA, G., NALEEZ-JAWEEKI, G., ULFIG, K., BRIGMON, R.L., 2005, The application of bioassays as indicators of petroleumcontaminated soil remediation. Chemosphere, 59:289-296. http:// dx.doi.org/10.1016/j.chemosphere.2004.11.049.

PLAZA, G.A., JANGID, K., ŁUKASIK, K., NAŁĘCZ-JAWECKI, G., BERRY, C.J., BRIGMON, R.L., 2008, Reduction of petroleum hydrocarbons and toxicity in refinery wastewater by bioremediation. B. Environ. Contam. Tox., 81: 329-333. http:// dx.doi.org/10.1007/s00128-008-9411-z.

SISINNO, C.L.S., RIZZO, A.C.L., BULUS, M.R.M., ROCHA, D.A., SORIANO, U.A., VITAL, R.L., MOREIRA, J.C., 2007, Application of ecotoxicological tests in a preliminary evaluation of soils treated on bioreactor. J. Braz. Soc. Ecotoxicol., 2: 157161. http://dx.doi.org/10.5132/jbse.2007.02.008.

SOBRERO, M.C. \& RONCO, A., 2004, Ensayo de toxicidad aguda con semillas de lechuga (Lactuca sativa L.). In: G. C. Morales (ed.), Ensayos Toxicológicos y Métodos de Evaluación de Calidad de Agua: estandarización, intercalibración, resultados y aplicaciones, IMTA, Mexico.

U. S. EPA (Environmental Protection Agency), 1996, Ecological Effects Test Guidelines OPPTS 850.4200 Seed Germination/ Root Elongation Toxicity Test, Washington DC.

VIDALI, M., 2001, Bioremediation: an overview. Pure Appl. Chem., 73: 1163-1172. http://dx.doi.org/10.1351/pac200173071163.

VWIOKO, D.E. \& FASHEMI. D.S., 2005, Growth response of Ricinus communis L (Castor Oil) in spent lubricating oil polluted soil. J. App. Sci. Environ. Manag., 9: 73-79. http://dx.doi. org/10.4314/jasem.v9i2.17294.

WANG, X., SUN, C., GAO, S., WANG, L., SHUOKUI, H., 2001, Validation of germination rate and root elongation as indicator to asses phytotoxicity with Cucumis sativus. Chemosphere, 44: 1711-1721. http://dx.doi.org/10.1016/S0045-6535(00)00520-8.

WONG, M.H. \& BRADSHAW, A.D., 1982, A Comparison of the toxicity of heavy metals, using root elongation of rye grass, Lolium perenne. New Phytol, 91: 255- 261. http://dx.doi. org/10.1111/j.1469-8137.1982.tb03310.x.

ZANG, X., PETERSON, C.L., REECE, D., HAWS, R., MOLLER, G., 1998, Biodegradability of biodiesel in the aquatic environment. T ASAE, 41:1423-1430. 